\title{
Diphtherietoxoid，免疫元性， 定量法二就于
}

（昭和 10 年 1 月 12 日受付）

傳染病研究所第入細菌血清學部(主任 細谷省吾博士)

田中哲之助

(本業績)大要八略和 9 年 4 月 3 日. 第 8 回聯合微生物學會, 涉ビ二同月 26 日. 傅染病研究所 集談會デ發表シ，實驗紫學雜誌第十入第五號二抄錄シタ)。

\section{緒 言}

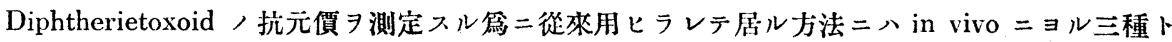
in vitro $ニ ョ ル ー$ 種がアル。

in vivo $=ョ ル$ 方法トシテ最初ニ舉グぶキ八海䐎免疫法卜モ謂フベキ方法デ，多ク八海猽二 Toxoid八一定量 ヨ注射スル。數週又八數ケ月 $\exists$ 經テ，之二最少致死量 $(\mathrm{mld})$ ）數倍乃至數百倍

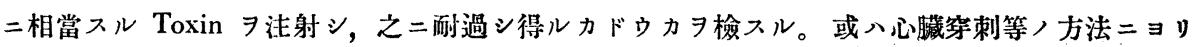
探血シテ血淸中，Antitoxingehalt ヨ測定スルト云フ栤ナコトニヨリToxoid／抗元性ヨ比較ス ル方法デアル。

コノ方法、Toxoid，抗元性 ヨ最モ確賽二登明シ得ル方法デハアルが, 何分二モ長時日 7 要ス ルコト、, Toxoid，比較的多量ヨ要スルコト、，多ク/海獏习用ヒナケレバ成績ノ信賴性 7 缺 クト云フ弱點习持ツテ居ルノデ, ソ, 使用價值ハ著シク減シラレル。蓋シ海猽, 個性差二基ク成

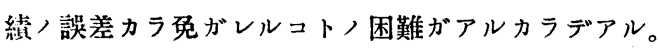

第 2 二時間的問題二就テ、Kraus ${ }^{(1)}$ ) 2 (2) (1925 年)等, 考案シタ Bindungswertmethode 八, ソ レヨ著シク短縮シ得タコト、, 更二抗元性ヨ數字デ表ハスコトニ成功シテ居ルハ八面白イ。ソレ 、Bächer 及ビ Löwenstein 卜，共同二係ハルモノデ, Ehrlich，Diphtherietoxin，間接價測 定法二基イテ居ル。皮下注射法ニョッテ Toxoid，抗元性 ヨ間接二测定スル方法デ, 後述スル著 者，方法，骨子トモナルベキモデアル。ソノ概要 ヨ迅ベレバ次ノ通リデアル。

Toxoid，遞隇量(例へバ 0.1c.a, 0.15c.c, 0.2c.c., 0.25 c.c.....) $=2 \mathrm{AE}$ ， Standardserum $尹$ 加へ 1 時間室溫二放置スル。

然ル後 $1 \mathrm{~L}+$ 量， $\mathrm{Toxin} \ni$ 適宜， $\mathrm{NaCl}$ 水デ稀程シタ液(通常 $2 \mathrm{coc}$ ) $\mathrm{NaCl}$ 水中 $=1 \mathrm{~L}+$ 量，

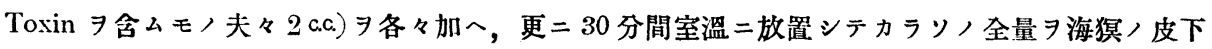
二注射シ， 7 日間觀察习續ヶル。ソシテ丁度 4 日目二獘レタ海晖カラ，ソレニ相當スル Toxoid 人最少量习求メ, Toxoid 1 c.c. 卜結合スル Serum, AE 7 計算スル。例へバ0.1ca, Toxoid = 相當スル Gemisch 7 注射サレタ海㩧が 6 日目二, 0.15 c.c.が 5 日目二, 0.2 c.c. が 4 日目二, 0.25 c.c.及ビ0.3c.aが 3 日目二䌘レタトスレバ，此，Toxoid，1c.c.八5 AE，Serum ト結合スル作 用郎チ抗元性ヨ有スルト云フノデアル。何故ナラバ丁度 4 日目二整レタ海猽二相當スル Toxoid 


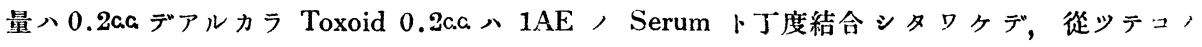
Toxoid ヘ $5 \times 0.2=1$ デ5AE，Serum 卜結合スル作用ヨ有スルコトが計算サレルカラデアル， 之ヨ B. W. 万per c.a. 卜記載スル。

コノ方法へ上逃セル海猽免疫法二比スレバ，時日ヨ短樎シ得タ點二於テ優レテ居ルが，多ク， 海猽习用ヒネバ個性差ノ大キナ弱點ヨ除クコト, 出來ヌコト、, 每回貴重ナ Standardserum 及 ビ Toxin 八相當多量习使用スル等ノ缺點がアル。加之其ノ制定二八侗木週餘习要スル。

第3 番自/方法八1928 年 =Glenny ${ }^{(3)}$ ニョッテ公ニサレタ方法デ，之八海猽免度法ニ於ヶル 毒素酎過試驗或、Antitoxingehalt 八測定二代ヘルニ Schicktest $コ$ 應用シタモノニ過ギナイ。

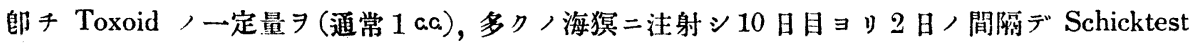
ヨ繰返シ行フ。ソシテ Schick 㓌性トナルニ至ル迄， test 回數ニョリToxoid，抗元性/比較 值ヨ示りウト云フノデアル。此/值 ヨ免疫系數 immunity index ト呼ビ，コ）方法ラ免疫系數测 定法 immunity index method(rapid index method)ト云フテ居ル。

コノ方法ハ一見シテ明カデアル樣二簡便ナ方法デハアルガ, 上述シタニッ,方法ト全ク同一， 弱點习持ッ玄居ル。

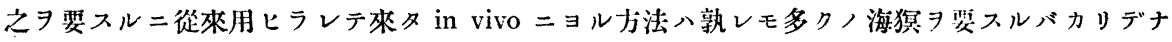
ク，夫二伴フ個性二基り成績，誤差カラ免がレ難ク，更二長時日ヨ要スル等，大ナル弱點がアル ノデ Toxoid，抗元性习測定スル上ニ少ナカラブ不便习感ブル。

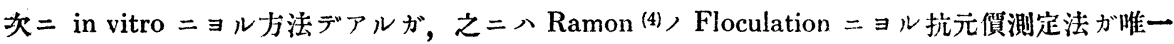
ノ方法トシテ存在スル。

毒素卜抗毒素トヨ試驗管內二混ゼテカラ暫ラク觀察シテ居ルト䋈狀，沈溉が生ジテ來ルコト 八暴 = Calmett et massol (5) ニョリ Cobragift トソレデ免度シタ馬血清間二, 次デ Nicolle ${ }^{(6)}$ 等ニョリDiphtherietoxin 或ハTetanustoxin ト夫レ等デ免疫サレタ馬血清間二登明サレタ所デ

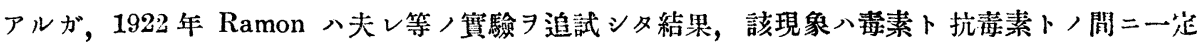
一關係ヨ以テ起ルコトヨ發見シ，之ニョリDiphtherie 血清ノ AE 及ビToxin(Toxoid)八抗元性 ヨ测定スルコトが出來ルト報告シタ。郎千 Antitoxin，版減量二一定量ノToxin 或ハToxoid 7 加へ室溫乃至 $50^{\circ} \mathrm{C}$ 二放置スルトキハ或ル試驗管入間モナク溷濁シ始メ次デ絮狀ノ沈溉トナッテ 管底二沈降スル。此八現象 7 Ramon 、Floculation 卜名付ヶ, 此八沈溉、Toxin 或八Toxoid 卜Antitoxin 卜ノ結合シタモノニ他ナラナイ。ソシテソノ最初ニ起ツタ部ニ於テハ Toxin 或八

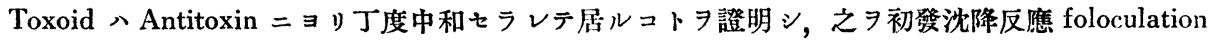
initiale ト名付ヶ此/部ニ於クル Toxin 或八Toxoid 及ビ Antitoxin /中，單位，明カナモ， ヨ基準トシテ他方未知ナルモ, 、單位 7 算出シ，之ニョッテ抗元價又八抗毒素量 ト企テタノデアル。

此ノ現象が Ramon ノ云つ通りToxin 或八Toxoid卜, Antitoxin 卜ノ完全中和ニョり起ルト

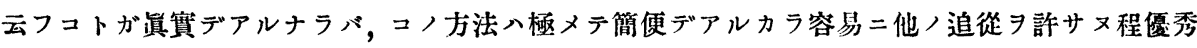
ナ方法デアルが，其ノ後諸學者ノ追試ノ結果該現象ノ本態二就テ肯定スルモノ、アルー才j，否症

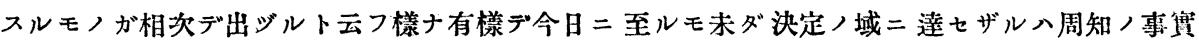
デアル。特二寺尾氏 (7)，如キ本邦學者八最近二於ケル周密ナル反駁報告 ナ方法ニヨり抗元性习測定スルコトハ佾早デアルト思フノデアル。（是等二關スル諸家ノ報告八 寺尾氏，論文中二引用サレテアルカラ省略シタ。)

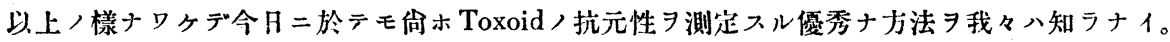




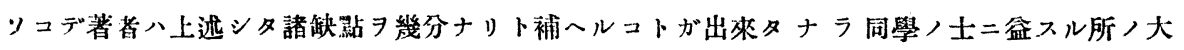

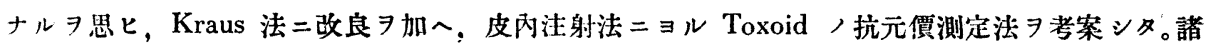
蜸, 御高批 7 仰グ次第デアル。

本法八Wadsworth ${ }^{(8)}$ ，皮內血清單位测定法 7 modifizieren シタモノデ，Prinzip 、Kraus 法 二準據シテ扂ル。

皮內注射法トシテ Römer (9) 法ᄏ擇バナカッタ理由八,コノ方法ハWadsworth 法二比較シテ 成綪、制定が困難デアルュト、數日ヨ要スル等ノ缺點がアル篇デアル。

证ッテ著者ノ方法ヨ述ベル前二順序トシテ Kraus 法及ビ Wadsworth 法二就テ語ル必要がア

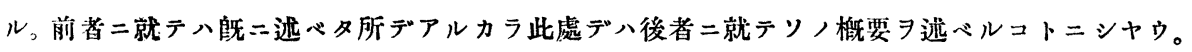

此, 方法八現今 Division of Laboratories and Research of the New-York State Department of Heath 二於テ行ハレテ居ル所謂 Standard methods トシテ知ラレテ居ル方法デ， $\frac{1}{50} \mathrm{AE}$ ， Standardserumト $\frac{1}{50} \mathrm{~L}+$ 量 Toxin トヨ等量二混ゼタモノ、0.1 a a 海猽ノ皮內二注射スルト， Toxin 、Serum /鹤メニ中和サレテ, 24 時間後局所八微二發赤スルガ 48 時間後二八消浪スル ト云ハレテ居ル。從ツテ血清カ毒素カノ中, 孰レカ一方ノ單位が明カデアルナラバ未知ナル他

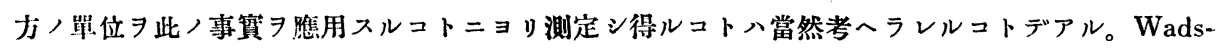

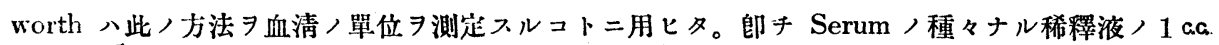

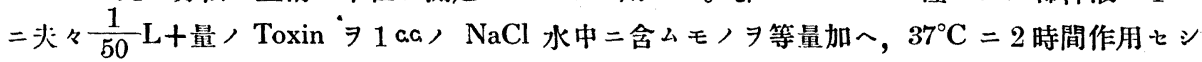

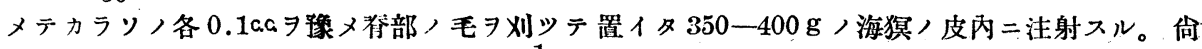
木此, 場合 Kontroll トシテ Toxin 液 $=\frac{1}{50} \mathrm{AE}$, Standardserum $尹$ 等量加へタモ, 同一海猽二注射スルコトヨ忘レテハナラヌ。カクシテ 24 時間後此, Kontroll 卜同一, 發赤 7 呈シ, 48 時間後同樣二渻裉スル血清, 最大稀晴量 $\exists$ 求メテ, 其ノ血清 1 c.c.中二含有スル抗毒素

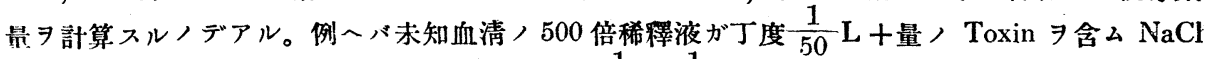
水，等量ト中和シタトフレバ，ソ，血清ハ $\frac{1}{500}: \frac{1}{50}=1: \mathrm{x}$ デ $10 \mathrm{AE}$, Antitoxin $ヨ$ 含有シ テ咸ルコトがワカル。

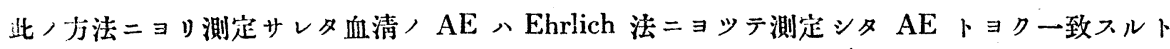

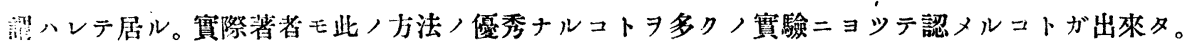

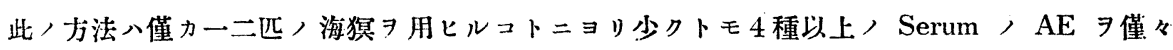

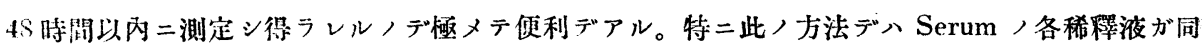

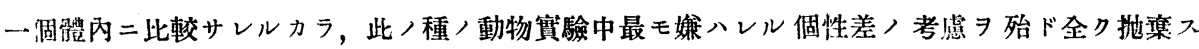
ルコトが出來ルコトハ洼目フベキデアル。

著省ハ此，皮內诘射法ニヨル優秀ナ長所 $\exists$ Kraus 法二隹用スルコトニヨリ從來，方法，弱點 ヨ著シク签減スルコトが出來タコトヨ欣快二思フ。モトヨリ動物 八出來ナイガ, ソレデモ本法ニョレバ䈣密ナ Kontroll ヨ同一個體內二求メラレルカラ, 極メテ

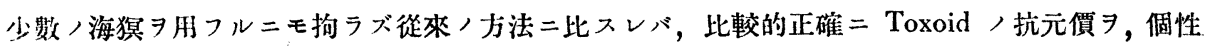

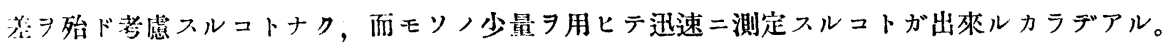

\section{原 理}

稀䖽シタ Toxoid 八一定量 $=\frac{2}{50} \mathrm{AE}$ ， Standardserum タ加ヘテ結合サセル。然 
ル後之二 $\frac{1}{50} \mathrm{~L}+$ 量，Toxin 丹加へ其，0.1 c.c. 海猽，皮內二注射スル。

24 時間卜 48 時間, 2 间二互ツテ觀察スルニ, 或ル Toxoid，稀釋液タ注射シタ㫛 所ガ微二赤色キ呈シ $( \pm), 48$ 時間後ニ至ツテ消褪(ー)シタトスレバ, ソノ稀釋 Toxoid 液ハ $\frac{1}{50} \mathrm{AE}$ ， Serum 卜丁度結合シタコトチ意味スルカラ，(何故ナラバ Wadsworth ニョレバ $\frac{1}{50} \mathrm{AE}$, Serum ト $\frac{1}{50} \mathrm{~L}+$ 量, Toxin ト，Gemisch ，0.1c.c. キ海猽， 皮內二注射スルトキハ, Toxin 八 Serum，鹞二中和セラレテ，24時間後局所二輕度 〉發赤キ生ジ 48 時間後消褪スルト云ハレテ居ルコト八前述シタ.通リデアル。本法二 於テハ $\frac{2}{50} \mathrm{AE}$ ，Serum 7 用七テ居ルカラ此，場合二ハ $\frac{1}{50} \mathrm{AE} ， \operatorname{Serum} 八$ 前處 置ニョリToxoid ト結合シテ失ハレ, 殘ル $\frac{1}{50} \mathrm{AE}$ ， Serum ガ後カラ加へラレタ $\frac{1}{50} \mathrm{~L}$ 十量，Toxin キ中和シタト考へラレルカラデアル。) ソ Toxoid，稀釋度カ ラ Toxoid 1 c.c. 結合スル Serum， $\mathrm{AE}$ ガ計算サレル。斯クシテ得ラレタ數字タ 以テ Toxoid ノ抗元價キ表ハソウト云フノデアル。

\section{所要材料}

測定用材料ハ第 1 表二一括シテ揭ゲタ。

試 藥

\section{第 1 表 测定用材料}

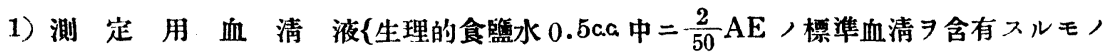

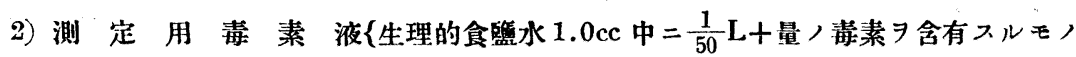
其 他
3）食
篮
水 $0.85 \%$ 生理的食監水

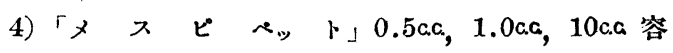
數本
5)「木ールピ ペト」50ca. 容
1 本
6) 中 試騟管徑 $1.7-1.8 \mathrm{~cm}$.
7)「エルレンマイエルコル 100a. 容
數 10 本
8) 洼
射・器「ッベルクリン」用 $1 \mathrm{aca}$
3 個
9) 注
射
針 $-\frac{1}{4}$ 或八 $\frac{1}{3} \mathrm{~mm}$. 可及的尖端鈍角ナルモ，
數個
10) 海
㩧體重 $600 \mathrm{~g}-700 \mathrm{~g}$
數個 2-3匹

3)-9）八滅菌シテ用フ。

\section{試藥ノ調製法}

I. 血清液: $0.85 \%$ 生理的食監水(以下 $\mathrm{NaCl}$ 水卜記入) $62 \mathrm{ccc}$ \% 100c.c. 容三角「コル ベン」ニ取リ, 0.5c.c. ） Standardserum ( 1 c.c. = 10AE キ含ムモノ) キ可及的正確二加へ ル。允分混和シテカラ使用スル。コ液 0.5 c.c. 中二ハ $\frac{2}{50} \mathrm{AE} ，$ Serum 7 含有スル。 


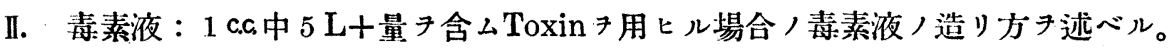
此ノ場合二ハToxin キ理論上 250 倍二稀释スレバ $\left(\frac{5}{250} \mathrm{~L}+=\frac{1}{50} \mathrm{~L}+\right) 1$ c.c.中 $\frac{1}{50}$ $\mathrm{L}+$ 量, Toxin キ含ムコトニナルワケデアルカラ, $49.8 \mathrm{ccc}$ ） $\mathrm{NaCl}$ 水キ入レタ三角「コル ベン」ニ, 此, Toxin ，0.2c.c.タ加へテ充分混和シテカラ使用スレバョイ。 $\frac{49.8+0.2}{0.2}$ =250)(然シ實際ニハ次二述ベル樣ナ方法ニョリToxin）稀釋度キ定メテカラ上述， 樣ニシテ毒素液き造ルコトガ肝要デアル。)

$\frac{1}{50} \mathrm{AE}, \operatorname{Serum}=ヨ$ 円和セラレ 24 時間後輕度, 發赤 $( \pm)$ チ生ジ，48 時間後 消螁スル Toxin 稀程度, 測定法 :

本法タ初メテ行フトキ或ハ新タ二調製シタ Standardserum 若シクハL+Toxin タ 用フルトキ著者ハ使用スル Toxin，皮內二於ケル中和點タ次ノ樣ナ方法デ測定シ， 用ヒル Toxin，稀釋度キ定メラカラ使用スルコトニシテ居ル。

例へバ L+量ガ 0.2c.c.゙ラアルト規定サレタ Toxin デ八次/ 8 稀釋液き造リ,
(1) $450 \times$
(2) $400 \times$
(3) $350 \times$
(4) $300 x$
(5) $250 \times$
(6) $200 \times$
(7) $150 \times$
(8) $100 x$

其，各 $1 \mathrm{c} . \mathrm{c}=\frac{1}{50} \mathrm{AE}$ ， Standardserum ( 1 c.c. = $10 \mathrm{AE}$ デアルナラバ 500 倍二稀释 シタモノ) キ 1 c.c.宛加へ $35^{\circ}-37^{\circ} \mathrm{C}=1$ 時間作用サ七ル。然ル後嶑入丁寧二脊部ノ毛 尹刈ツタ 2 匹 海猽 $(600$ 一 $700 \mathrm{~g})$ ）皮內二第 2 表, 樣二上記番號，順二夫々 $0.1 \mathrm{ccc}$ 宛

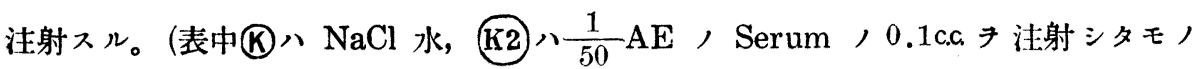
デ Kontroll デアル。)

ソシテ $2+$ 時間後及ビ 48 時間後, 結果尹 精密二觀察シ 24 時間後發赤(一)) 稀釋度 ト(十) 人稀釋度ト，2點キ擇ビ，例へバ $300 \times$ ガ(ー)デ $200 \times$ ガ(十)デアルナラバ

第 2 表

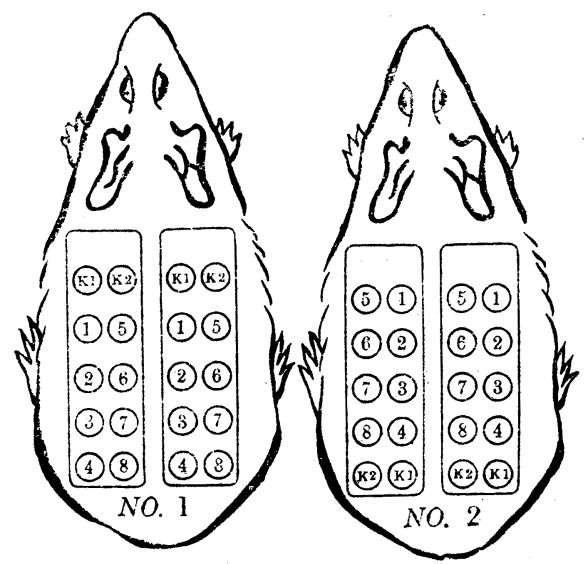

$300 \times+200 \times$ 間二於テ
(1) $300 \times$
(2) $275 \times$ (3) $250 x$
(4) $225 \times$
(5) $200 \times$

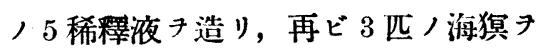
用七テ同樣二測定シ, 24 時間後 $( \pm)$, 48 時間後(一)トナル稀釋度 7 求メル。 カクシテソノ稀释度ガ求メラレタナ ラバ，ソノ稀釋度キ中心トシテ前後 2 稀释例へバ $250 \times$ カ該稀釋度二當儿上 キ八
(1) $270 \times$
(2) $260 x$
(3) $250 \times$
(4) $240 x$
(5) $230 \times$ 


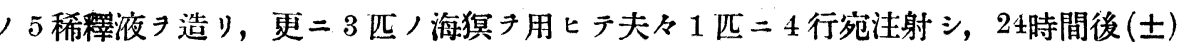
デ 48 時間後(一)トナル最モ多イ稀釋度キ求メル。カクシテ測定二用ヒル毒素液, 稀 䆏度き定メル。

I 液 II 液ハ共二保存二耐へナイカラ每測定前二新二稀釋シテ用ヒル。

\section{Toxoid ノ稀釋ノ仕方}

測定法キ述ベル前二順序トシテ Toxoidノ稀釋度ノ定メ方二就テ述ベル。

Toxoid ノ稀釋法八吻論任意デョイガ著者八原毒素調製䈏初ノ mld ノ明カナ場合 ニハ，之キ基準トシテ大體ノ範圍キ定メルコトガ便利デアルコトチ知リ得タノデ次ニ 述べル樣ナ方法ニヨリ其ノ稀釋度定メテ居ル。

ソレニハ mld キ 4 デ割ツタ商ノ近クノ稀釋液キ數種類造レバョイ。例へバ原毒素調 製當初ノ mld ガ $\frac{1}{500}$ c.c.デアルナラバ, 500 キ 4 デ割ツタ商郎チ 125 倍近クノ稀䆁液 數種類造ツテ測定スル。mld 間接價トハ勿論常ニ一致スルモノデハナイガえニヨッ テ Toxoid ノ抗毒素結合力ガ大體ドノ程度デアルカテ囨想スルコトハ出來ル。

上述 mld チ 4 デ割ル理由ハ次ノ通リデァル。

Ehrlich 二據レバ $1 \mathrm{AE}$ ， Serum ハ1mld，100倍二相當スル Toxin キ中和ス ル作用テ持ツテ居ルワケデアルカラ, Toxin ガ毫モ破壞サレズニ全部 Toxoid 化サレ タモノト假定スルナラバ, $1 \mathrm{AE}$ ， Serum ハ 1mld，100倍，Toxin二相當スル Toxoid ト結合スル理デァル。從ツテ $\frac{1}{50} \mathrm{AE}$ ， Sreum ハ1mld， 2 倍，Toxin 二 相當スル Toxoid ト結合スル作用ガアル。本法デハ0.5c.c.八稀釋 Toxoid 液キ用ヒテ 居ルカラ (後述測定法ノ項參照), 此ノ理ニヨリ其ノ 1 c.C.ハ 4 mld , Toxin 二相當入 ルコトキ知ル。換言スレバ本法デ用フル Toxoid，稀釋度ト mld ト 1:4 關係ガ アルワケデァル。

$$
\begin{aligned}
& \text { 稀釋度 }: \text { mld }=1: 4 \\
& \therefore \text { 稀㩐度 }=\frac{\text { mld }}{4}
\end{aligned}
$$

デアルカラ mld キ 4 デ割ツタ商ニ Toxoid チ稀释スレバ略ボソ, Toxoid 液 0.5 c.a八 $\frac{1}{50} \mathrm{AE}$ ，Serum 卜結合スル近クニ置カレル理デアル。

貫際ニ滀ツテ著者八Toxoidノ本法ニヨル間接價ハ多ク/場合，カクシテ定メタ稀 釋度ノ近クニアルコトキ經驗シタ。

\section{測 定 法}

A）本試驗：稀释シタToxoid 液 0.5 c.c. チ試驗管二取リ, 血清液 0.5 c.c. チ加へ能ク 
混和シ, $35^{\circ} \mathrm{C}-37^{\circ} \mathrm{C}=1$ 時間放置スル(途中 30 分目 $=1$ 回振漫スル)。次デそ二毒素 液 1 c.c. 加へ更 $=35^{\circ}-37^{\circ} \mathrm{C}=1$ 時間作用サ七ル (途中 1 回振燙スルコトハ前ト同樣

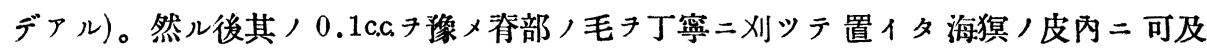

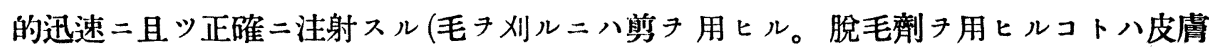
チ害スル懼レガアルカラ避ケル)。

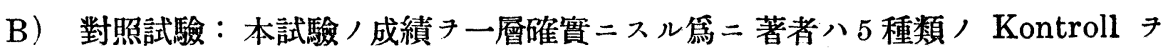
置クコトニシタ。

（1）中和對照。血清液 更 $=4$ 倍二稀釋シタ液 1 c.c. $\left(\frac{1}{50} \mathrm{AE} ，\right.$ Standardserum 含有スル) $35^{\circ}-37^{\circ} \mathrm{C}=1$ 時間放置シテカラ, 之二毒素液 1 c.c.加へ再ビ 同溫同時 間放置シ其, 0.1 c.c. 宛丹同樣二注射スル。

之八成績制定, 指針トモナル最モ重要ナKontrolle ノーツデ, 本試驗, 成績八常ニ 之二比較シテ定メル。

(2) 毒素對照。 $\mathrm{NaCl}$ 水 1 c.c.二毒素液 1 c.c. $ォ$ 加へ $35^{\circ}-37^{\circ} \mathrm{C}=1$ 時間放置シテカラ 其, 0.1c.c. キ同樣二注射スル。

(3) 血清對照。血清液 $0.5 \mathrm{ccc},=\mathrm{NaCl}$ 水 $0.5 \mathrm{ccc}$ キ加へテ $35^{\circ}-37^{\circ} \mathrm{C}=1$ 時間放置後

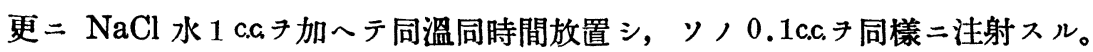

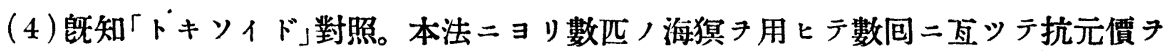
測定シ, ソノ價ノ一定シテ居ル Toxoid キ用七抗元價附近ノ稀程液キ 5 種類造ツテ本 試驗二準ジテ血清液及ビ毒素液キ作用サセ，ソノ0.1c.c. 宛キ同樣二注射スル。

此, Kontroll 八本法デ八通常 2 匹ノ海猽ヨ用七テ居ルノデ, 往々海猽間二成績ノ 差尹生ズルコトガアルガ, ソノ樣ナ場合二成績キ制定スル參考ニナル。又 Toxoid， 抗元性ガ非常二强クテ各稀釋液, 凡テガ發赤シタ場合若クハ反對二弱クテ毫モ發赤シ ナイ場合 (後述抗元性)强弱卜皮內反應/項參照) 換言スレバ求メル Toxoid，抗毒素 結合力ガ測定二供シタ稀釋圈外ニアル場合, ソノ實驗ガ誤リデアッタカ否カキ制定ス ルノ二輕メテ重要性フ持ツテ居ル。或ハ中和對照, 正確フ證明スル助ケトナル。

(5)檢液對照。Toxoid，稀釋液中其ノ稀釋度ノ最モ小ナル液郎チ最モ濃厚ナル液 $0.5 \mathrm{ccc}$ 二血清液 $0.5 \mathrm{ccc}$. ヲ加へ $35^{\circ}-37^{\circ} \mathrm{C}=1$ 時間放置後, $\mathrm{NaCl}$ 水 1 c.a. 加へテ再ビ 同溫, 同時間放置シタ後其，0.1c.a 向同樣二注射スル。(第 3 表)

Toxoid ト Serum 及ビ夫ト Toxin トノ作用時間八敦レモ1時間卜記載シテ置イタが夏季 ニ於テハ夫ィ 30 分二短縮シテ同一，結果が得ラレタカラ妶ニ記シテ置ク。

\section{北里大学图書館}


本 試 驗

第 3 表 测 定 法

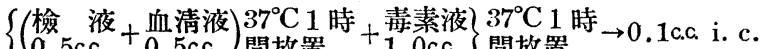

䔄

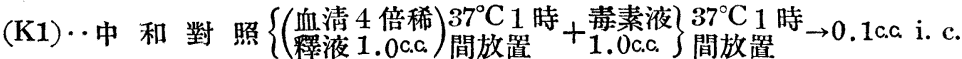

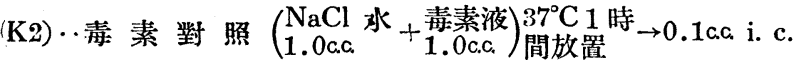

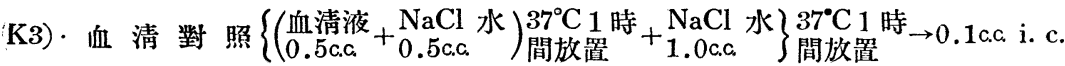

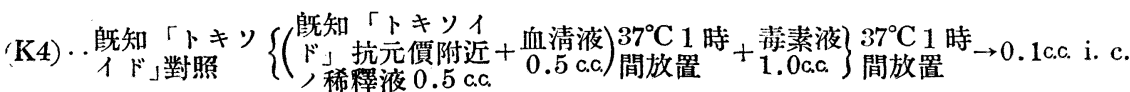

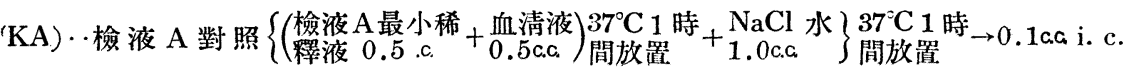

KB) ․ 檢液 B 對照 $\{$ (檢液 B , + , ) , + , \} ,

(KC) $\cdots$ 檢液 $\mathrm{C}$ 對照 $\{($ 檢液 $\mathrm{C}$

\section{皮內注射ノ仕方}

Toxoid ノ稀釋液八第 4 表二見ル通り 1 種類二就テ通常 5 種類造り(從ツテ 1 匹)游: 猽デ少クトモ 3 種類, Toxoid，抗元價キ比較測定スルコトガ出來ル)，測定法 $\mathrm{A}=$ 準ジテ血清液及ビ毒素液キ作用サセ其ノ 0.1 c.c. 宛キ表中(5)ヨリ (1)二间ツテ可及的迅速 二注射スル。

注射器及ビ注射針ハToxoid 液 1 種類ニ付イテ 1 個宛用意シテ置ク。ソシテ稀釋液 ノ變ル每二注射シャウトスル液ノ少量デ少クトモ2 回以上洗條シテカラ使用スル。

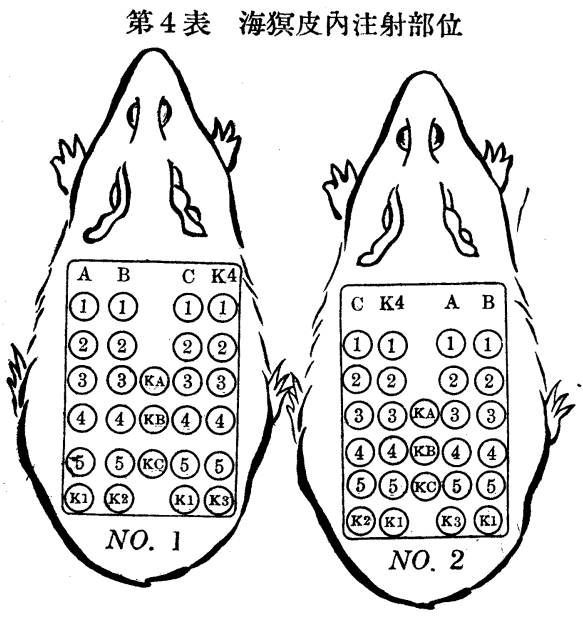

稀釋法ノ一例

\begin{tabular}{|c|c|c|c|c|c|}
\hline \multirow{2}{*}{ 檢液 } & \multicolumn{2}{|r|}{ 稀 } & \multicolumn{3}{|c|}{ 度 } \\
\hline & (1) & (2) & (3) & (4) & (5) \\
\hline A & $100 \times$ & $87.5 \times$ & $75 \times$ & $62.5 \times$ & $50 x$ \\
\hline B & $225 \times$ & $200 \times$ & $175 \times$ & $150 \times$ & $125 x$ \\
\hline $\mathrm{C}$ & $250 x$ & $187.5 \times$ & $125 \times$ & $\overline{62.5 \times}$ & $25 x$ \\
\hline $\mathrm{K} 4{ }^{*}$ & $125 \times$ & $112.5 \times$ & $100 x$ & $87.5 \times$ & $75 \times$ \\
\hline (K1) & K2 & K3 & (KA) & (KB) & (K4) \\
\hline
\end{tabular}


第 4 表ハ注射法及ビ Toxoid 液ノ稀释ノ仕方ノ1例タ示シタモノデ, A 八抗元傮 $2 \mathrm{AE}$ (後述抗元價記載ノ仕方參照) ヨリ $4 \mathrm{AE}$ 迄 $0.5 \mathrm{AE}$ 間隔二, $\mathrm{B}$ 八同ジク $5 \mathrm{AE} ヨ$ リ

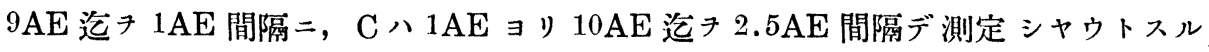
トキノ Toxoid ノ稀釋度キ示シタモノデ, Toxoid /抗毒素結合力ノ全ク想像ノ付カ ナ!樣ナ場合二大體, 見當キ付ケル目的デ測定スルトキ二此ノ樣ナ稀釋法ガ使ハレ ル。蓋シ显通, Toxoid デアルAnatoxin デハ殆ド凡テ此ノ範園デソノ抗元性ノ大 體キ知ルコトガ出來ルカラデアル。

\section{抗元性ノ强弱卜皮內反應卜ノ關係}

上述セル如ク稀釋シタ Toxoid ガ $\frac{1}{50} \mathrm{AE}$ ， Serum ニョリ丁度中和サレタトキ 八 24 時間後仙處二輕微ノ發赤 $( \pm)$ ガ起リ 48 時間以內二消褪 $($ 一) スルガ，Toxoid；

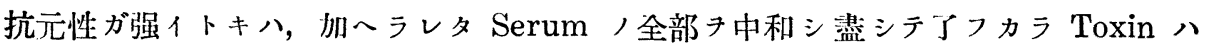
Serum ト結合セズ其鰛殘ル。從ツテ發赤ハ 24 時間後著明二現ハレルバカリデナク 48 時間後ニハ㸝々ソノ程度キ增シ終ニハNekrose キ生ズルニ至ル。

之二反シテ抗元性ガ弱イトキハSerumハ $\frac{1}{50} \mathrm{AE} ヨ$ 過剩二殘ル理デアルカラ毒 素ハ完全二中和サレテ 24 時間後或ハ 48 時間後ニ至ルモ發赤キ生ズル樣ナコトハナイ。

第 5 表 抗元性卜皮內反隹卜，關係

\begin{tabular}{|c|c|c|c|c|}
\hline \multirow{5}{*}{ 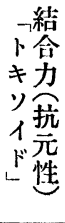 } & \multirow{2}{*}{$\begin{array}{l}\frac{1}{50} \mathrm{AE} \text { 血 } \\
\text { 清 } ョ リ\end{array}$} & \multirow{2}{*}{$\begin{array}{l}\text { 殘餘血清量ハ } \\
\frac{1}{50} \mathrm{AE} \text { ヨリ }\end{array}$} & 反 & 㗹 \\
\hline & & & $24^{\mathrm{h}}$ & $48^{h}$ \\
\hline & 强 & 少 & + & + \\
\hline & 等 & 等 & \pm & - \\
\hline & 弱 & 多 & - & - \\
\hline
\end{tabular}

デアルカラ本法ニ於テ發赤シタ場合二 八抗元性ノ强イコトタ示シ, 發赤ノ現 ハレナイトキニハ抗元性ノ弱イコトキ 示スノデアル。(第 5 表)

發赤八 Toxoid，抗元性，强サ二從 ツテ色々ノ程度デ現ハレル。

\section{觀察及ビ判定ノ仕方}

觀祭ハ 24 時間ト 48 時間, 2 包二瓦ツテ行フコト八前述ノ通リデァル。ソシテ中和 對照ト同樣二, 24 時間後發赤輕度 $( \pm)$ デ 48 時間後消褪 (一) スルカ 或八發赤ノ減退入 ル點キ中和點ト定メルコトキ原則トシテ居ル。ケレドモ海猽ノ個性ニヨリ 48 時間後 中和對照が消褪シナイバカリデナク反ツテ增大スル樣ナコトヤ時ニハ 24 時間後 (十) , コトモアルノデ，斯カル場合ニ八中和對照ガ誤リデナイコトキ躰知トキソイド對照タ 參考ニシテ確カメタ上, 尖ト同一程度ノ發赤タ呈スル若クハ同樣ノ經過き辿レル部位 ヨ中和點ト定メルコトニシテ居ル。カクシテ定メタ Toxoid ノ抗元價八順調二行ハレ 
タ時ノ成績ト殆ド一致シテ居タコトチ十數包/實驗デ確メタカラデアル。

又或ル稀释度ガ發赤 $(+)$ デ次ノ稀釋液ガ (ー) デアルトキ八中和點ハソノ本均值 ト ルガ, 要スレバ其ノ間ノ稀釋液き數種類造ツテ再度,實驗き試ミル。

各海猽間二中和點ノ相違 生ジタ場合モ同樣本均值キ以テ中和點卜定メル。

發赤ノ程度, 定メ力八測定者ノ見方ニョリ多少ノ差ノアルノ八常然デアルガ, 常二 既知トキソイド對照キ參考ニシテ，中和對照ト同一程度/發赤キ呈七ル部位キ中和點 ト定メルナラ, 能ク一致シタ成績ガ得ラレルコトハ傳染病研究所第八細菌血清學部， 諸兄き煩ハシテ數包確カメタ處デァル。

\section{抗元價ノ記載ノ仕方}

・ Toxoid 1 c.c. 結合スル血清, 單位キ次式ニョッテ計算シ, そキ以テ抗元價キ記ス コトニシタ。

$$
\text { 抗元價 }=\frac{\text { 中和點ニ於ヶル Toxoid 八稀释度 }}{25} \text { per c.G }
$$

ソシデ上式ニョッテ得ラレタ數字ノ前 $=\operatorname{Li}($ Liemes immunisum) ナル符號キ附シ テ從來用ヒラレテ居ル方法デ測定シタ抗元單位卜區別シタ。例へバ中和點ニ於ケル Toxoid 八稀釋度ガ 125 倍デアルナラバ, 此，Toxoid／抗元價八上式ニヨリ5デア ルカラ, そき記スル $=\mathrm{Li} 5$ per c.c. 又ハ $\mathrm{Li}=5 \mathrm{AE}$ per c.c.トスル。其, 1 c.c.八 $5 \mathrm{AE}$ ノ抗毒素ト結合スル作用ガアルコトタ意味スル。

上式ノ 25 デ中和點ニ於ケル Toxoid，稀釋度き割ル理由き說明スレバ次ノ通リデ アル

本法デハ稀释 Toxoid，0.5c.c. ガ中和點二於テ $\frac{1}{50} \mathrm{AE} ，$ Serum ト結合スル 理デ アルカラ (上交參照) 稀釋 Toxoid 1 c.c.八 $\frac{2}{50} \mathrm{AE}$ 郎 $\frac{1}{25} \mathrm{AE}$ ，Serum ト結合スル。 故 $=1 \mathrm{AE}$ ， Serum ト結合スル Toxoid八稀釋夜, 25 c.c. タ要スル。

Probe

\begin{tabular}{|c|c|c|c|}
\hline & Toxoid ノ種類 & $\begin{array}{c}\text { 原毒素 } \\
\text { mld }\end{array}$ \\
\cline { 3 - 4 } A & No. 190 普通アナトキシン(1) & $\frac{1}{300}$ c.c. \\
\hline B & No. 54 精製アナトキシン(2) & $\frac{1}{300}$ c.c. \\
\hline C & No. 63 精製アナトキシン(3) & $\frac{1}{500}$ c.a \\
\hline
\end{tabular}

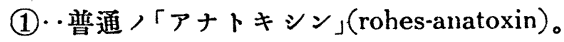

(2). 細谷. 宮田法(10) ニョル所謂精製毒素 I

ヨリ出發七ル Anatoxin。

(3)‥(1) 7細谷. 宮田法デ精製シタモノ。
從ツテ稀釋度チ 25 デ割レバ 原 Toxoid，1 c.c.八1 AE， Serum ノ何倍ト結合スルカト 云フコトガワカル。

\section{惯 驗}

\section{I. 實驗例 :}

左記 3 種類 / Anatoxin /抗 
元價キ測定シタ仕方キ一例トシテ揭ゲル。

(1) Toxoid /稀釋。A及ビ B ハ mld $\frac{1}{300}$ c.c. ，Toxin カラ造ツタモノデアルカラ, 其ノ抗毒素結合價,$\frac{1}{350}$ c.c.乃至 $\frac{1}{150}$ c.c. 間ニアルモノト想像シ, 其ノ間ノ稀釋液 5 種類 キ造ツテ測定シタ。郎チ $\operatorname{mld}$ キ 4 デ割ツタ數.
(1) $87.5 \times\left(\operatorname{mld} \frac{1}{350}\right.$ c.c.トシテ $)$
(2) $75 \times\left(\operatorname{mld} \frac{1}{300}\right.$ c.c.トシテ $)$
(3) $62.5 \times\left(\mathrm{mld} \frac{1}{250} \mathrm{c}\right.$. $\mathrm{k}$ ト シテ $)$
(3) $50 \times\left(\operatorname{mld} \frac{1}{200} \mathrm{c} . \mathrm{c}\right.$ ト シテ $)$
(5) $37.5 \times\left(\operatorname{mld} \frac{1}{150}\right.$ c.c.トシテ $)$

ナル稀釋液告ツタ。

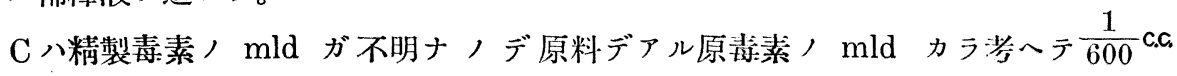
乃至 $\frac{1}{200} \mathrm{c} . \mathrm{c}$ 間ノ稀釋液キ造リ，其ノ抗元性き測定シタ。郎チ次ノ通りデァル。
(1) $150 \times\left(\operatorname{mld} \frac{1}{600} \operatorname{c.c.}\right.$ ト シテ $)$
(2) $125 \times\left(\operatorname{mld} \frac{1}{500} \mathrm{ccc}\right.$ ト シテテ
(3) $100 \times\left(\operatorname{mld} \frac{1}{400}\right.$ c.c.トシテ $)$
(4) $75 \times\left(\mathrm{mld} \frac{1}{300} \operatorname{ccc}\right.$ 卜 シテ $)$
(5) $50 \times\left(\operatorname{mld} \frac{1}{200}\right.$ c.c.トシテ $)$

上記 A B C 各稀釋液 0.5c.c. 試驗管二可及的正確二取リ血清液 $70.5 \mathrm{ccc}$. 宛加へル。

(2) 對照。次デ Kontroll トシテ本法ニヨリ數回抗元性き測定シ，其ノ間接價ノ一

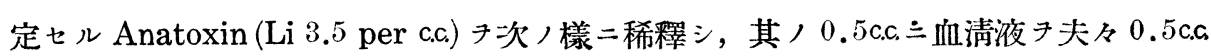
宛加へタモノ(既知トキソイド對照 $\mathrm{K} 4$ ),
(1) $112.5 \times$
(2) $100 \times$
(3) $87.5 \times(\mathrm{Li} 3.5$ per c.c. 二相當スル稀釋度)
(4) $75 \times$
(5) $62.5 \times(0.5 \mathrm{AE}$ 間隔稀釋法デアル)

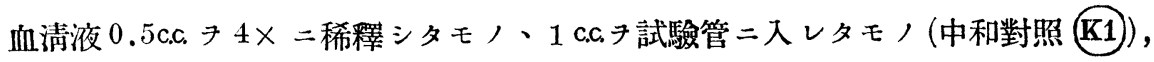
$\mathrm{NaCl}$ 水 1 c.c. キ試驗管二入レタモノ(毒素對照占2)，

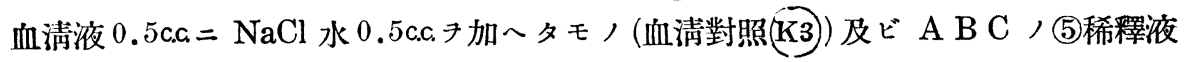

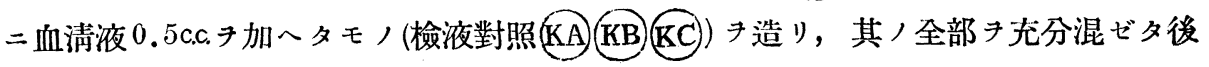
$35^{\circ}-37^{\circ} \mathrm{C}$ ) 恒溫器中二 1 時間放置スル。ソシテ約 30 分後試驗管キ取り出シテ輕ク振

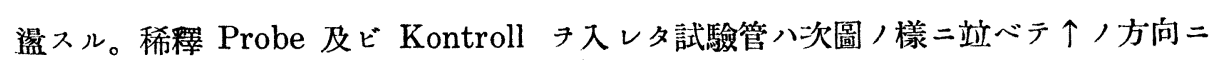
血清液或ハ毒素液ヨ一度二加へデ行クト便利デアル。
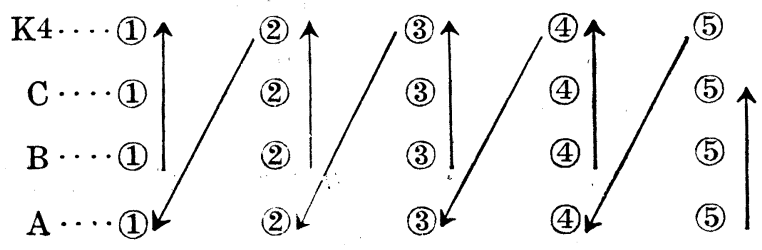

$\frac{(\mathrm{KC})}{\mathrm{KB}}$

(K1). K2. K3 


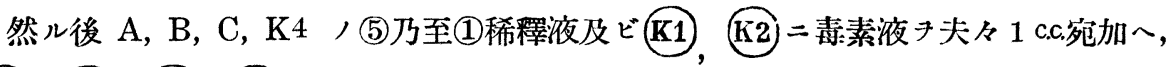
(K3), (KA), (KB), (KC) $=\mathrm{NaCl}$ 水 1 c.c.宛加へル。光分振湦混和シテカラ再ビ $35^{\circ}$ 一 $37^{\circ} \mathrm{C}$ 二放置スル。

1 時間後 (途中 1 包振蕰スルコトハ前ト同樣デアル) 恒溫器カラ各試驗管キ出シテ,

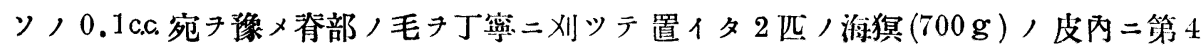
表ノ如ク(5)ヨリ(1)二间ツテ可及的迅速二注射スル。

第 $\quad 6 \quad$ 表

24 時間後

48 時間後
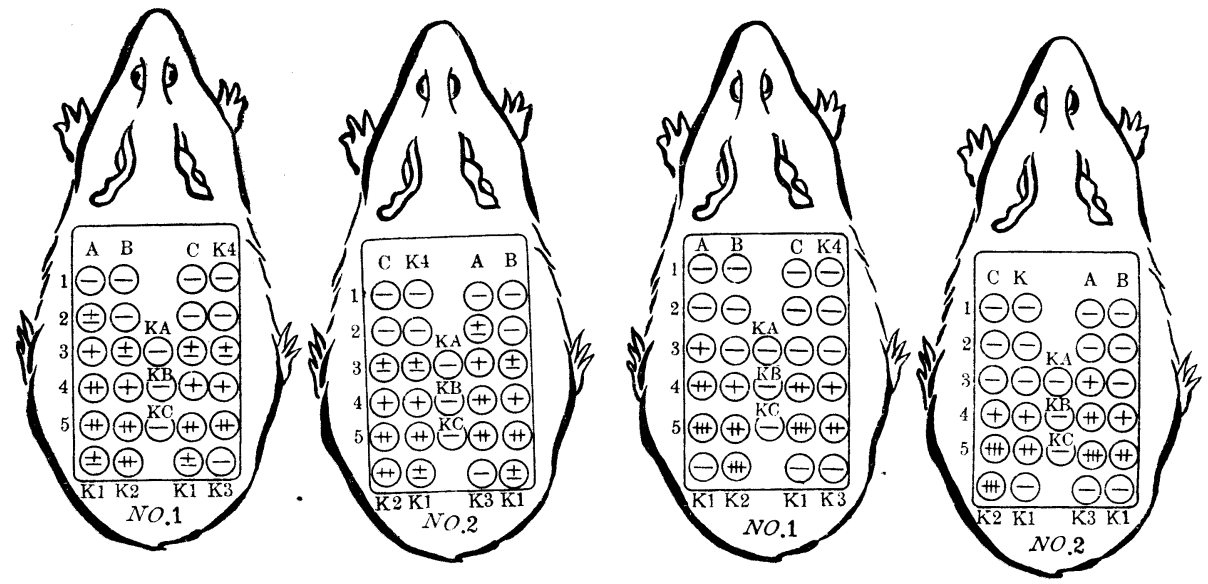

24 時間後及ビ 48 時間後觀察スルニ第 6 表ノ樣ナ結果キ得タ。

師于 $\mathrm{A}$ 八(2) $=75 \times, \mathrm{B}$ 八(3) $=62.5 \times, \mathrm{C}$ 八(3) $=100 \times, \mathrm{K} 4 八(3=87.5 \times$ 稀釋液二於 テ(K1)卜同樣 24 時間後微二發赤シ, 48 時間後消螁シテ居ル。

從ツテ $\mathrm{Li}$ ハ次ノ通リデアル。
$\mathrm{A} \cdots \frac{75}{25}=3$
$\therefore \quad$ Li 3 per c.c.
$\mathrm{B} \cdots \frac{62.5}{25}=2.5$
$\therefore \quad \operatorname{Li} 2.5$ per c.c.
C $\cdots \frac{100}{25}=4$
$\therefore \quad$ Li 4 per c.c.
$\mathrm{K} 4 \cdots \frac{87.5}{25}=3.5$
$\therefore \quad$ Li 3.5 per c.c.

郎チ No. 190 晋通 Anatoxin ，1 c.c. 3AE， Antitoxin ト結合スル能力キ有シ， No. 54 精製 Anatoxin , 1 c.c.八 2.5AE, No. 63 精製 Anatoxin， 1 c.c.八 4AE， Antitoxin ト結合スル能力ノアルコトキ知ツタ。

第 7 表ハ同樣ニシテ 普通 Anatoxin 及ビ細谷. 宮田法ニョリ精製シタ所謂精製 Anatoxin I ノ抗元價 $1 \mathrm{AE}$ 間隔デ測定シタモノデァル。 
第 7 表 本法ニョリ測定セルー例

\begin{tabular}{|c|c|c|c|c|c|c|c|c|c|c|c|}
\hline \multirow{2}{*}{ 種類 } & \multirow{2}{*}{$\begin{array}{c}\text { 「ナト } \\
\text { キシン」 } \\
\text { No. }\end{array}$} & \multirow{2}{*}{$\begin{array}{l}\text { 觀察 } \\
\text { 時間 }\end{array}$} & \multicolumn{5}{|c|}{ 「アナトキシン稀釋液 } & \multirow{2}{*}{$\begin{array}{l}\text { 檢液 } \\
\text { 對照 } \\
25 \times\end{array}$} & \multirow{2}{*}{$\underset{\times}{\text { 中和點 }}$} & \multirow{2}{*}{$\mathbf{L i}$} & \multirow{2}{*}{ 對照 } \\
\hline & & & $25 \times$ & $50 \times$ & $75 \times$ & $100 \times$ & $125 \times$ & & & & \\
\hline \multirow{6}{*}{ 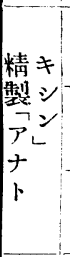 } & \multirow{2}{*}{53} & $24^{\mathrm{h}}$ & $H$ & + & + & \pm & - & - & \multirow{2}{*}{100} & \multirow{2}{*}{4} & \multirow{2}{*}{$\begin{array}{l}\text { 中 } \\
\text { 和 }\end{array}$} \\
\hline & & $48^{h}$ & tt & t+ & + & - & - & - & & & \\
\hline & \multirow{2}{*}{62} & $24^{\mathrm{h}}$ & $+t$ & $+t$ & $+t$ & $+t$ & \pm & - & \multirow{2}{*}{125} & \multirow{2}{*}{5} & \multirow{4}{*}{$\begin{array}{l}24^{\mathrm{h}} \pm \\
48^{\mathrm{h}}\end{array}$} \\
\hline & & $48^{h}$ & tt & $H$ & tt & + & - & - & & & \\
\hline & \multirow{2}{*}{$6: 3$} & $24^{\mathrm{h}}$ & $H$ & $t+$ & $t+$ & + & \pm & - & \multirow{2}{*}{125} & \multirow{2}{*}{5} & \\
\hline & & $48^{\mathrm{h}}$ & tt & + & $H$ & \pm & - & - & & & \\
\hline \multirow{4}{*}{$\begin{array}{l}\text { ア キ } \\
\text { ナシ } \\
\text { トレ }\end{array}$} & \multirow{2}{*}{198} & $24^{h}$ & $H$ & tt & + & \pm & - & - & \multirow{2}{*}{100} & \multirow{2}{*}{4} & \multirow{4}{*}{$\begin{array}{c}24 \mathrm{~h}+1 \\
48^{\mathrm{b}}++ \\
\text { 血 } \\
\text { 清 }\end{array}$} \\
\hline & & $48^{h}$ & tt & $t+$ & + & - & - & - & & & \\
\hline & \multirow{2}{*}{201} & $24^{h}$ & tt & t+ & + & \pm & - & - & \multirow{2}{*}{100} & \multirow{2}{*}{4} & \\
\hline & & $48^{h}$ & $+t$ & $H$ & + & - & - & - & & & \\
\hline \multirow{2}{*}{$\begin{array}{l}\text { 對 } \\
\text { 照 }\end{array}$} & \multirow{2}{*}{$\begin{array}{l}\mathrm{Li} 4 \overline{\Gamma ア ナ} \\
\text { トキシン」 }\end{array}$} & $24^{h}$ & tt & tt & + & \pm & - & - & \multirow{2}{*}{100} & \multirow{2}{*}{4} & \multirow{2}{*}{$\begin{array}{l}24^{\mathrm{h}}- \\
48^{\mathrm{h}}-\end{array}$} \\
\hline & & $48^{\mathrm{h}}$ & $t+$ & $t+$ & + & - & - & - & & & \\
\hline
\end{tabular}

本法尹 Toxoid，研究二用七タ例二就テハ細谷. 利部兩氏卜共二, 或八細谷. 利部 及ビ門馬,三氏ト共二行ッタ, , Diphtherietoxoid，精製” “就テノ研究中デ詳細二 報告シテ置イタカラ次ノ論文キ參照セラレタイ。

紼谷. 田中. 利部 : Japan. journ. exp. med., 12; No. 3, 1934.

" " " : : Compt. rend. soc. Biol., 116 ; 1161, 1934.

, " , : 實驗醫學雜誌, 第 18 卷, 第 7 號, 昭和 9 年.

，"，"：第 19 卷, 第 2 號, 昭和 10 年.

練谷. 田中. 利部. 門馬：東京醫學會雜誌, 第四十八卷, 第十二號, 2556 頁, 昭 和 9 年.

II. 對照實驗 : 次二對照トシテ, 加熱 Diphtherie-anatoxin, 細谷. 宮田法 ${ }^{(1)}=\Xi ル$ 精製破傷風毒素カラ造ツタ所謂精製破傷風アナトキシン」I, 站ビニ Martin bouillon キ用ヒテ, 本法ニョリ抗元價フ測定シテ見タガ, 第 8 表ニ示ス如ク孰レモ發赤セズ,

$\mathrm{Li}$ ハOデァツタ。

此ノコトハ本法ガ Diphtherietoxoid /抗元性ノ測定法トシテ特異的價値ノアルコ トキ示シテ居ル。

III. Li ト Kraus 法ニョル B. W. 卜 關係 : 本法ニョッテ測定シタ抗元單位卜 Kraus 法ニョル夫ト, 間二八差がアルカドウカ, 若シモ差がアルナラバ夫ガ常ニ一 定ノ比キナシテ居ルカドウカト云フコトハ㥛メテ重要ナ事ナノデ慎重二實驗き試そタ ガ㕵通 Anatoxin 二於テモ, 精製 Anatoxin I ニ於テモ亦显二細谷. 利部兩氏ト共二 
第 8 表 對 照 筫 驗

\begin{tabular}{|c|c|c|c|c|c|c|c|c|c|c|c|c|c|}
\hline \multirow{2}{*}{ 種 } & \multirow{2}{*}{$\begin{array}{c}\text { 觀 } \\
\text { 時間 }\end{array}$} & \multicolumn{4}{|r|}{ 稀 } & \multicolumn{2}{|c|}{ 釋 } & \multicolumn{3}{|l|}{ 液 } & & \multirow{2}{*}{$\begin{array}{l}\text { 中 } \\
\text { 和 } \\
\text { 點 } \times\end{array}$} & \multirow{2}{*}{$\mathrm{Li}$} \\
\hline & & $1 \times$ & $5 \times$ & $10 \times 2$ & $25 \times$ & $50 \times$ & $75 \times$ & $100 \times$ & $125 \times$ & $250 x$ & & & \\
\hline \multirow{2}{*}{$\begin{array}{l}\text { (對照) No. } 45 \text { 精 } \\
\text { 製アナトキシン」 }\end{array}$} & $24^{\mathrm{h}}$ & & & & tt & Ht & \pm & - & - & & \pm & \multirow[t]{2}{*}{50} & \multirow{2}{*}{2} \\
\hline & $48^{\mathrm{b}}$ & & & & Ht & \pm & - & - & - & & - & & \\
\hline \multirow{2}{*}{$\begin{array}{l}\text { 同上加熱「アナ } \\
\text { トキシン」 }\end{array}$} & $24^{\mathrm{h}}$ & \pm & - & - & - & - & & & & & \pm & \multirow{2}{*}{0} & \multirow{2}{*}{0} \\
\hline & $48 \mathrm{~h}$ & - & - & - & - & - & & & & & - & & \\
\hline \multirow{2}{*}{$\begin{array}{l}\text { 「マルタンブイ } \\
\text { ヨン」 }\end{array}$} & $24 \mathrm{~h}$ & \pm & & - & - & - & - & & & & \pm & \multirow[t]{2}{*}{0} & \multirow[t]{2}{*}{0} \\
\hline & $\overline{48 \mathrm{~b}}$ & - & & - & - & - & - & & & & - & & \\
\hline \multirow{2}{*}{ 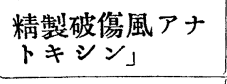 } & $24^{\mathrm{h}}$ & - & & - & & - & & - & & - & - & \multirow{3}{*}{0} & \multirow{3}{*}{0} \\
\hline & $48 \mathrm{~h}$ & - & & -1 & & - & & - & & - & - & & \\
\hline 對 & & & 中和 \{ & $\left\{\begin{array}{l}24^{\mathrm{h}} \\
48^{\mathrm{h}}\end{array}\right.$ & & & $x_{2}^{2}\left\{\begin{array}{l}24 \\
48\end{array}\right.$ & $3 \mathrm{ll}$ & 血清 & $\left\{\begin{array}{l}24^{\mathrm{h}} \\
48^{\mathrm{h}}\end{array}\right]$ & & & \\
\hline
\end{tabular}

報告シタ,粉末狀精製トキソイド”ニ於テモ敦レノ場合二於テモ Li ト B . W . 卜 大體二於テ能ク一致シテ居ルコトキ知ツタ。1 例タ示セバ次ノ通りデアル。

Li 3.5 per c.c. ナル No. 41 精製 Anatoxin， 2.5 倍液, 3.5 倍液及ビ 4.5 倍液尹

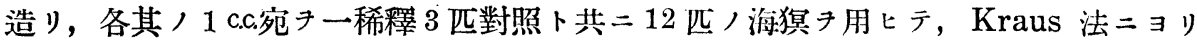
第 9 表 皮內抗元單位 $(\mathrm{Li})$ 卜皮下抗元單位 $(\mathrm{B} . \mathrm{W})$ 卜，比較 No. 41 精製アナトキシン」Li 3.5 per c.c. (Kraus 法 $=\exists ル$ )

\begin{tabular}{|c|c|c|c|c|c|c|c|}
\hline \multirow{2}{*}{$\begin{array}{l}\text { 「アナトキシ } \\
\text { ン量 }\end{array}$} & \multirow{2}{*}{ 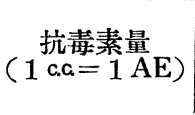 } & \multirow{2}{*}{ 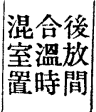 } & \multirow{2}{*}{$\begin{array}{c}\text { 後二添加セ } \\
\text { ル毒素量 } \\
(0.2 c . c=1 \mathrm{~L}+)\end{array}$} & \multicolumn{4}{|c|}{$\begin{array}{l}\text { 更二室溫 } 30 \text { 分放置後海 } \\
\text { 注㢰シタ績 }\end{array}$} \\
\hline & & & & No. & 生宏 & $\begin{array}{l}\text { 死二至 } \\
\text { 政 }\end{array}$ & 症狀 \\
\hline \multirow{3}{*}{$2.5 \times$ 液 1 c.c. } & \multirow{3}{*}{2 c.c. } & \multirow{3}{*}{$1 \mathrm{~h}$} & \multirow{3}{*}{$0.2 \mathrm{ccc}}$. & 191 & 死 & 3 & Typ \\
\hline & & & & 192 & 死 & 3 & $"$, \\
\hline & & & & 193 & 死 & 3 & " \\
\hline \multirow{3}{*}{$3.5 \times$ 液 1 c.c. } & \multirow{3}{*}{2 c.c. } & \multirow{3}{*}{$1 \mathrm{~h}$} & \multirow{3}{*}{$0.2 \mathrm{c.c}}$. & 194 & 死 & 3 & ", \\
\hline & & & & 195 & 死 & $3 \frac{1}{2}$ & ," \\
\hline & & & & 196 & 死 & $2 \frac{1}{2}$ & ", \\
\hline \multirow{3}{*}{$4.5 \times$ 液 1 c.c. } & \multirow{3}{*}{2 c.c. } & \multirow{3}{*}{$1 \mathrm{~h}$} & \multirow{3}{*}{0.2 c.c. } & 197 & 生 & - & -- \\
\hline & & & & 198 & 坐 & $-\cdot$ & - \\
\hline & & & & 199 & 生 & - & - \\
\hline \multirow{3}{*}{$\begin{array}{l}\text { 對 } \\
\text { 照 }\end{array}$} & \multirow{3}{*}{\multicolumn{3}{|c|}{$\begin{array}{l}\text { 「血清 }=1 \mathrm{~L}+\text { 量ノ毒素习加へ室溫 } \\
\text { 後海㩧〉皮下=注射セル成績 }\end{array}$}} & 61 & 死 & 3 & Typ \\
\hline & & & & 62 & 死 & 3 & ," \\
\hline & & & & 63 & 死 & $2 \frac{1}{2}$ & \\
\hline
\end{tabular}

抗元價キ測定スル。第 9 表ニ見ル如ク, 2.5 倍及ビ 3.5 倍稀釋液, 注射ナ受ケタ 6 匹 ノ海猽八對照デァル 1 單位, Serum $=1 \mathrm{~L}+$ 量, Toxin キ加へタ 3 匹, 海猽卜同樣 孰レモ 3 日以內二定型的症狀ノモト二整死シタガ, 4.5 倍稀釋液き注射シタ海猽 3 匹 ハ7 日後ニ至ルモ沿ホ元氣デアッタ。郎チ B.W. 八 Li ト同樣 $3.5 \mathrm{AE}$ per c.c.デ兩者 八能ク一致シテ居ル。 
IV. Li 卜免疫效果卜）關係: Kraus 法ニヨリ測定シタ Toxoid，抗元單位卜免疫 效果卜, 關係二就テハ, 既二本邦二於テモ大坪 ${ }^{(12)}$, 肥田, 久保野 ${ }^{(13)}$ 氏等二ヨッテ報告 サレ，孰レモKraus 單位ノ高イモノ程强1晦疫元性ノアルコト7認メテ居ル。

著者モ亦本法二ヨル抗元單位ガ Kraus 法ニヨル夫ト一致スル以上, 免疫效果二於 テモ同樣, 關係ガアルノデハナカラウカト思ツタノデ, 日常傳染病研究所第八細菌血 清學部デ調製シテ居ル多ク，Diphtherie-anatoxin ノ中，本法ニョッテ抗元價テ測 定シタ數種類キ擇ビ, 淮猽き免度シ, 17 日目ニ於ケル Schick 陰性轉化率キ比較シテ 見タ。

第 10 表 $\mathrm{Li}$ 卜免疫能力卜, 關係

(Toxoid 注射 17 日目二於ヶル Schick 陰性轉化率)

\begin{tabular}{|c|c|c|c|c|c|c|c|c|c|}
\hline \multirow[b]{2}{*}{ 種類 } & \multirow[b]{2}{*}{ No. } & \multirow[b]{2}{*}{$\begin{array}{c}\mathrm{Li} \\
\text { (Per c.c.) }\end{array}$} & \multirow{2}{*}{$\begin{array}{l}\text { 注射量 } \\
\text { (抗 元 } \\
\text { 單 位) }\end{array}$} & \multirow[b]{2}{*}{ 海猽數 } & \multicolumn{4}{|c|}{ 『シックテスト」 } & \multirow{2}{*}{ 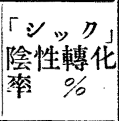 } \\
\hline & & & & & $\begin{array}{l}\text { 「テスト」 } \\
=\text { 至ル日 } \\
\text { 數 }\end{array}$ & 海晖激 & 反臀別 & 海晖數 & \\
\hline \multirow{6}{*}{ 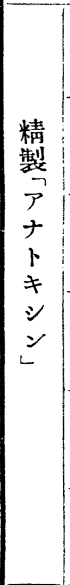 } & 27 & 0.75 & 0.75 & 15 & 17 & 14 & \pm & $\begin{array}{r}13 \\
0 \\
1\end{array}$ & 7 \\
\hline & 27 & 0.75 & 2.25 & 10 & ", & 10 & $\begin{array}{l} \pm \\
\pm\end{array}$ & $\begin{array}{l}9 \\
0 \\
1\end{array}$ & 10 \\
\hline & 49 & 1.5 & 7.5 & 5 & ," & 5 & $\begin{array}{l} \pm \\
\pm \\
-\end{array}$ & $\begin{array}{l}2 \\
0 \\
3\end{array}$ & 60 \\
\hline & 50 & 2 & 10 & 5 & , & 5 & \pm & $\begin{array}{l}1 \\
1 \\
3\end{array}$ & 60 \\
\hline & 1 & 2.5 & 12.5 & 5 & .. & 5 & \pm & $\begin{array}{l}1 \\
0 \\
4\end{array}$ & 80 \\
\hline & 62 & 4 & 20 & 10 & ," & 9 & \pm & $\begin{array}{l}0 \\
0 \\
9\end{array}$ & 100 \\
\hline \multirow{2}{*}{ 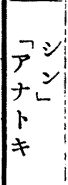 } & 200 & 2.25 & 11.25 & 5 & ", & 4 & $\begin{array}{l} \pm \\
\pm\end{array}$ & $\begin{array}{l}0 \\
1 \\
3\end{array}$ & 75 \\
\hline & 201 & 3.5 & 17.5 & 5 & , & 4 & \pm & $\begin{array}{l}0 \\
0 \\
4\end{array}$ & 100 \\
\hline
\end{tabular}

第 10 表二示スノ八夫デ，注射單位量ノ增減卜 Schick 除性轉化率ノ增減卜八海猽 ノ少ナイ惑えハアルガ大體二於テ本行シテ居ル事實き認メタ。

更二實驗フ確實ナラシメル䉆二，上表ニ於ケル:Schick 㓌性ノ海猽 28 匹二免疫後 21 日目 (Schick test 後 4 日目) 二夫々 $300 \mathrm{mld}$ 二相當スル Toxin キ注射シタカ凡テ 之二耐過シタ。.Schick 陽性者 25 匹二就テ八第 11 表二示ス樣二初注射ョリ28 日乃至 30 日後再ビ Schicktest キ行ヒ 30 日乃至 43 日キ經テ (初注射ョリ), 夫々陰性轉化者 
ニハ $300 \mathrm{mld}$, 俘ホ陽性ナルモノニハ $20 \mathrm{mld}$-30 mld 二相當スル Toxin キ注射セル 二, 前者八敦レモヨク之二耐過シタガ, 後者八悉ク 7 日以內二定型的症狀ノモト二幣 レタ。第一间 Schick test 二於テ (士) / 海猽 2 匹ハ 28 日後敦レモ陰性二轉化シタ， デ 30 日後 $300 \mathrm{mld}$ 二相當スル Toxin キ注射シタガ 7 日後元氣デァッタ。

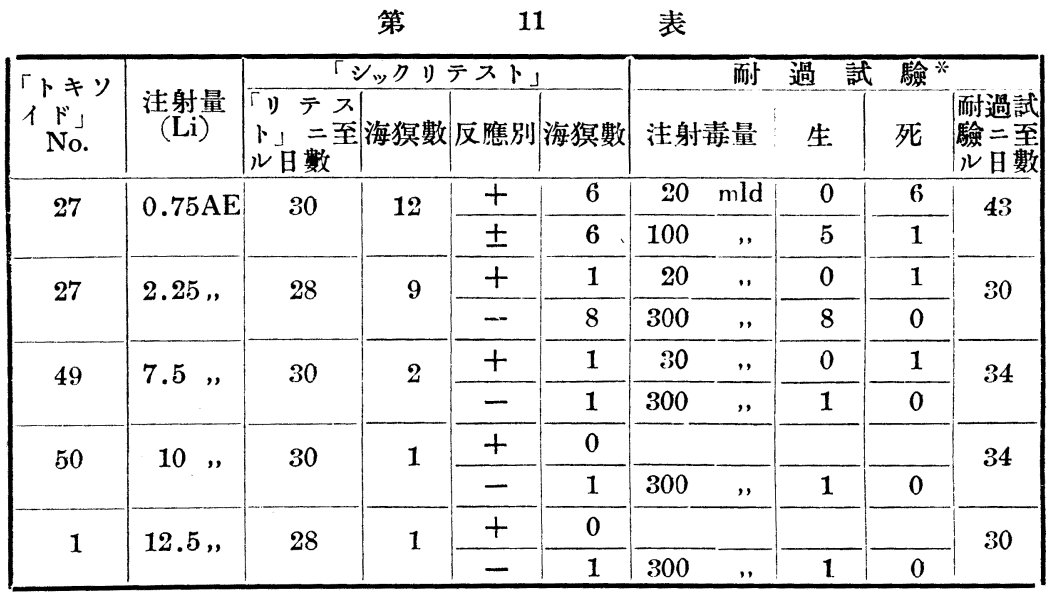

* 觀察日數 7 日

之キ要スルニ，本法ニヨツテ測定シタ抗元單位ハ Toxoid，免疫元性キ示スモノデ アルト考へラレル。

\section{測定ニ用ヒル海猽二就テ}

一般二皮內注射法き行フ二常リ最モ肝要ナコトハ，用ヒル動物キ充分注意シテ擇ビ 出スコトデァル。

從來 Römer 法或八Wadsworth 法等/如キ皮內測定法キ反䮎スル諸家/報告尹 見聞スル二, 其ノ多クハ使用スル動物二對シテ充分ナ注意ノ拂ハレテ居ナカツタコト き見受ケルコトハ遺憾二堪へナイ。若シ測定者ガ充分ナ注意ノ下二動物 擇ンデ用 フルナラバ，皮內測定法二於テモ每常殆ド同樣ナ滿足シ得ル結果，得ラレルコトタ Wadsworth 法二於テモ, 本法ニ於テモ, 或八 MRD 測定スル場合ニ於テモ著者八 親シク經驗シタカラデアル。

西村氏(14) (Diphtherietoxin 二對スル海猽ノ感受性二ハ著シイ差ノアルコトキ認

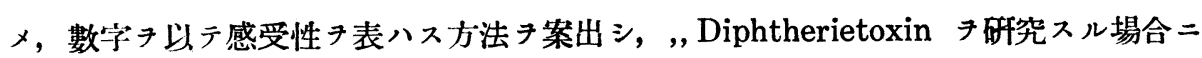

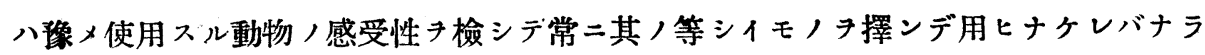
又”ト報告シテ居ル。 
著者ハ經驗上海猽二就テハ，外觀ダケデモ略ボ個性差，尠イモノキ擇ビ出スコトガ 出來ル樣ニナツタノデ以下數行二瓦ツテ此ノ方法テ紹介シャウト思フ。

1) 體重。西村氏ニョレバ Diphtherietoxin 二對久ル海猽ノ感受性八體重卜密接 ナ關係ガアル。體重ノ小ナルモノ八個體的差異ガ甚ダシク，且ッ一般二感受性小ナル 二反シ，大ナルモノ八皮內注射ニヨル毒素, 最少反應量, 本均小ニシテ且ツ個體的差 異モ尠イ。從ツテ皮内測定用二供スル海猽ハ少クトモ $400 \mathrm{~g}$ 以上ノモノキ用ヒナケレ バナラヌ。

Coca 及ビ其 /共同研究者 ${ }^{(15)} モ$ 亦，體重大ナル海猽八感受性一般二大デァル，且ツ 個體的差異ガ尠イカラ Römer 法二於テハ $400 \mathrm{~g}$ 以上ノ海猽き用ヒナケレバナラヌト 主張シテ居ルコトハ西村氏，實驗二合七テ適切ナ注意デアルト思フ。

著者モ亦小サイ潄猽八多クノ實驗ニヨッテ個性差ガ著シイコトキ認メタノデ，加え 注射部位ガ狹イカラ，多クノ稀釋液二就テ測定スル本法二八不適當 デアルノデ $600 \mathrm{~g}$ 乃至 $700 \mathrm{~g}$ ／海猽き常二用コルコトニシテ居ル。此ノ位ノ大サノモノニナルト個性差 八皮內反應二於テ八殆ド認メラレヌ程小ナル場合ガ極メテ多イカラデアル。又注射ス ルトニ極メテ便利デアル。

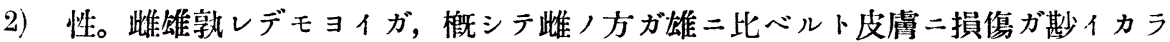
使用二適スル。然シ妊娠及ビ產裖中ノ海猽八避ケナケレバナラヌ。西村氏ハ此ノ樣ナ海 猽八感受性ガ小デアルト記載シテ居ル。從ツテ正常海猽ノ皮內反應量デハ反應七ズ, 測 定ノ誤謬丹招ク曜レガアルカラデアル。著者モ亦此ノ樣ナ海猽ハ $\frac{1}{50} \mathrm{~L}+$ 量, Toxin 注射シテモ 24 時間後毫モ發赤シナイ場合ガ多カッタコトタ記憶スル。然シ興味アル コトハ, カ、ル浭猽二皮內注射スルト 24 時間以內二流產スルコト7屢了見ル。此， 樣ナ場合二ハ48時間後二至ツテ始メテ發赤ガ現ハレテ來ルコトデァル。從ツテ誤ツテ 此ノ樣ナ海猽き用ヒタトキハ 48 時間後及ビ 72 時間後ノ結果 觀察シテ參考二供スル。 妊娠海猽, 皮膚ガ何故 Toxin 二對シテソノ樣ナ態度キトルカハ未ダ不明デァル。

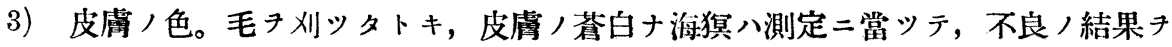
辩ラスコトガ多イカラ可及的避ケル必要ガアル。

微二赤味キ帶ビタ，多少光澤ノアル且ツ elastisch weich ナ皮膚キ持ツ海猽フ最良 トスル。

皮膚八乾燥シテ居ル樣ナ感ジノスルモノ，毛根ノ密ナルモノ，及ビ長毛(「アンゴラ」 種)或ハ卷毛(「ペルー,アビシニア種)，海猽モ不良ナ結果キ與へル場合ガ多イカラ注 意スベキデァル。 


\section{總括竝ビ ニ結論}

1)上述シタ如ク著者ハ皮內洼射法ニョルDiphtherietoxoid，間接價測定法ヨ考 案シタ。

2) 本法ニョッテ測定シタ Toxoid /抗元傮 キ便宜上 Li ト云フ略號デ表ハシ從 來ノ方法ニヨッテ測定シタ抗元價ト區別スルコトニシタ。

3) 本法ニョッテ測定シタ Toxoid，抗元價八Kraus 法ニョル抗元價二一致ス ル。

4） Li 高キ Toxoid 八免疫元性又强ク，Toxoid，抗毒素結合力卜免疫元性卜八實 驗範圍內二於テ, 本行スルコトキ認メタ。

5) 本法ニヨレバ嚴密ナル Kontroll タ同一個體內二求メラレルカラ從來ノ方法二 比ベルト極メラ少數ノ海猽キ用フルニモ拘ラズ，比較的正確二Toxoid，抗元價 尹, 個性差尹考慮スルコトナク，而モ其／少量 (通常 0.5 c.c.) キ用七テ迅速二測定シ得ル便 ガァル。

終リ二臨ミ長與前所長站ビ二宮川所長二謹ンデ敬意フ表シ，終始御愁篤ナル御指導 ト御鞭韃キ賜ハツタ恩師細谷博士二滿腔ノ謝意き捧ら゙ル。

又本㸴究二際シ貴重ナル標準血清及ビ毒素ノ御分與キ辱ナウセル田宮教授泣ビ二第 二細菌室横井. 中野兩氏二感謝スル。

仯ホ川島四郎氏. 桑島謙夫氏站ビ二第八細菌血清學部諸兄／御援助キ深謝スル。 本研究費ノ一部八服部献公會, 補助テ仰イダ。記シテ弦二謝意テ呈スル。

\section{蔘考文獻}

1) Kraus, Bächer u. Löwenstein, Zeitschr. f. Immunitäts-forschung. Bd. 42, S. 364, 1925.

2) H. Schmidt, Die Praxis der Auswertung von Toxin u. Antitoxin. 1931. 3) A. T. Glenny and Hilda Waddington, The Journ. of patholgy and bacteriology, Vol. 31, S. 403, 1928. 4） ラモ之, 城井份義全譯, 第八回日本醫學會誌. 5) Calmette et Massol, Ann. de l'Inst. Pasteur. 1909, 23, 155 . 6) Nicolle, Cesari et Debains, Ann. de l'Inst. Pasteur. 1920, 34, 594. 7) 寺尾秀三, 賽驗醫學雜誌, 第十七卷, 第一號, 昭和 8 年 1 月. 8) Wadsworth, Standard methods. p. 353, The William \& Wilkins Co. baltimore. 1927. 9) Römer, P. H., Zeitschr. f. Immunitätsforsch., 1909. III. 208. 10) 細谷省吾, 宮田重雄, 實驗醫學雜 誌, 第十四卷, 第十號, 昭和 5 年 10 月. 11）細谷省吾, 宮田重雄, 賽驗醫學雜誌, 第十四卷, 第入號, 昭和 5 年 8 月. 12) 大坪德一, 大阪醫學會誌, 第三十一卷, 第十二號, 昭和 7 年 12 月. 13）肥田, 久保野, 細菌學雜誌, No. 451, 1933.14 ) 西村治雄, 滿洲醫學會雜誌, 第十卷，第六號，昭和 4 年 6 月. 15) Coca, A. F., Russel, E. F. and B-aughman, W. H. Journ. Imm., 1921. Vol. 387. 